\title{
Economic Development and Growth in Central and Eastern Europe
}

\author{
Csilla Polster (ID https://orcid.org/0000-0002-1174-8802 \\ University of Győr, Faculty of Economics, Department of Leadership \\ and Organisational Communication, Győr, Hungary \\ e-mail: polster.csilla@sze.hu
}

\section{Abstract}

The study investigates the economic growth in Central and Eastern Europe in the last 25 years. The economy can be regarded as a substantial topic in any country, but it is even more interesting in developing countries. One of the basic ideas of the European Union is the convergence between member states, namely the reduction of development disparities, which can be achieved through faster economic growth in less-developed countries.

Growth theory is one of the main topics in economics. Its significant importance is because the desire for development is one of the main driving forces of mankind.

The aim of the study is to reveal the crucial differences and common features between the growth paths of the eleven Central and Eastern European member states of the European Union.

After presenting growth theories, the growth performance of the examined Central and Eastern European member states is pinpointed.

During the research, GDP per capita, population, migration, activity rate, employment rate, unemployment rate, foreign direct investment and foreign trade openness are considered.

Keywords: economic indicators, labour market processes, economic growth

JEL: E10 


\section{Introduction}

The study aims to reveal the economic growth in Central and Eastern Europe between 1995 and 2019. The economy can be regarded as a major topic in any country, but it is even more inspiring in developing countries.

Growth theory is one of the main topics in economics. Its significant importance is because the desire for development is one of the main driving forces of mankind.

Although economic growth is only a piece of this development, in addition to its direct impacts, it can also contribute to other social development approaches.

One of the basic ideas of the European Union is the convergence between member states, namely the reduction of development disparities, which can be acquired through faster economic growth in less-developed countries.

According to Lengyel and Varga (2018), the world economy started to develop rapidly in the $20^{\text {th }}$ century, with developed countries serving as an example for developing countries.

The study is made up of two parts. Firstly, it discusses general issues related to growth theory, and secondly, it examines the growth performance of Central and Eastern European member states between 1995 and 2019 in the light of the growth theories. The surveyed countries include the eleven Central and Eastern European countries of the European Union: Bulgaria, the Czech Republic, Estonia, Croatia, Poland, Latvia, Lithuania, Hungary, Romania, Slovakia and Slovenia.

Although there are substantial differences between the growth paths of the individual countries, similarities also emerge. Each of the surveyed economies can be divided into three main phases over the past 25 years: 1) transformational decline, 2) convergence period, 3) recession.

The study ends with a summary and conclusion in which I also cover the economic growth prospects of the countries.

\section{Literature review}

In this chapter, the following concepts, models and approaches are introduced: economic growth, general economic indicators, demographic and labour market processes, foreign direct investment and foreign trade openness.

\section{Economic growth}

Creating new jobs and maintaining a growing proportion of GDP (gross domestic product) in a rapidly developing market can be considered an important issue in a modern economy. The high level of progression in developing countries is a significant issue. A modern economic model based on continuous progress can lead to a boom in the economy (Wysokińska 2018). 
Krajewska and Krajewski (2020) pointed out that in some countries, the share of employment-related costs is even above $50 \%$ of GDP and is characterised by relatively high stability in the long term. High unemployment can lead to the spread of unethical activities. They concluded that the current labour market situation in many countries needs to be changed, and there is a need to introduce legal solutions that strengthen the position of employees in their relations with employers.

Economic and demographic development are closely interrelated, and it is very difficult to determine the cause and consequence of this economic and demographic development. The European population is generally in the process of demographic ageing, with differences from country to country. However, by analysing demographic aspects, some connections between economic convergence and demographic differences can be recognised. The structure of the workforce and the economic population is one of the most important aspects in planning and managing the economy (Eichenauer and Klee 2013).

Two contradictory trends can be observed in national investment policies. On the one hand, there are liberalisation, promotion and facilitation measures. On the other hand, there is the regulation of foreign direct investment. It was pointed out that countries have external powers concerning foreign direct investment and that that uncertainty can negatively affect the extent of foreign direct investment. (Witkowska 2020)

Young and more qualified workers will migrate from underdeveloped regions to developed parts of the country. As a result, age structure and educational standards will deteriorate in these regions (Kilper and Klee 2018).

The practice of foreign direct investment is far ahead of theoretical approaches. Gudowski and Piasecki (2020) underlined that the theories dealing with foreign direct investment deal with the cooperation of Western economies. Then, the growing trend of the open economy and globalisation emerged. In less-developed countries, there is a significant demand for foreign direct investment.

The countries of Central and Eastern Europe have undergone a rapid metropolitan transformation in the last two decades, although the process is delayed and is still dynamic with general and some specific features. This change was mainly reflected in the physical and functional transformation of large cities, which became the primary beneficiaries of the new economic and political system. At the national level, the development of the urban hierarchy has led to the growing dominance of capitals. The observed parallel trends include the declining importance of medium-sized cities and differentiation of small settlements in respect of functionality and regionalism (Korcelli and Korcelli-Olejniczak 2015).

Outward foreign direct investments and inward foreign direct investments can be distinguished. Outward foreign direct investments can be considered a negative phenomenon since they export occupations and practices to other countries, whereas inward foreign direct investments are identified with a more positive aspect since they facilitate occupations and reduce the need for imports. Bathelt and Buchholz (2019) claimed that outward investments have a positive cumulate effect in the domestic regions since they have access to foreign markets and new knowledge. 
Central Europe shows significant differences and temporal variability in the spatial delimitation of the region. In chronological order, natural German dominance (the concept of Central Europe) can be perceived as a transitional zone between Germany and Russia (or the Soviet Union) and can be considered an independent third region of Europe. Currently, the area designated as Central Europe usually contains Austria, the Czech Republic, Germany, Hungary, Poland, Slovakia, and sometimes Slovenia and Switzerland (Bláha et al. 2016).

Economic and demographic development are closely interrelated, and it is very difficult to determine the cause and consequence of this economic and demographic development. The European population is generally in the process of demographic ageing, with differences from country to country. However, by analysing demographic aspects, a connection between economic convergence and demographic differences can be recognised. The structure of the workforce and the economic population is one of the most important aspects in planning and managing the economy (Manić, Popović, and Mitrović 2016).

Regarding the failure of Mexico's economic policy, Parnreiter (2013) argued that the Mexican government's main goal with the North American Free Trade Agreement was to increase imports of working capital from the U.S. and Canada and to stimulate capital inflows to help to create jobs. He stressed that foreign capital goods also boosted private investments. However, Mexico has not been able to change its economic and foreign trade structure, and as a result, many Mexicans have left their homeland. He highlighted that Mexico's economy could not grow. Trade liberalisation caused growth in only a few manufacturing industries. Its foreign trade was also behind that of the United States, and Mexico was unable to take part in globalisation processes. This study is related to the topic because it investigates foreign trade.

After the change of regime, Hungary was characterised by a balance between the West and the East. Molnár and Lengyel (2016) highlighted that global production was facilitated by foreign direct investment.

Based on Solow's growth model, it can be asserted that in many sectors (agriculture, manufacturing, communications), the amount of capital per employee, or capital intensity, increased. Capital intensity increases while technological change, natural resources, the quantity and quality of work remain unchanged. The increase of capital intensity can cause a growth in the output per worker (Somogyi 2016).

Another variable to the Solow model can be added so that the evolution of physical and human capital are completely analogous. The explanatory power of the Solow model was substantially enhanced by the inclusion of human capital in the model (Mankiw, Romer, and Weil 1992).

Examining the fundamental causes of economic growth is an important topic. Empirical research has often shown the phenomenon of conditional convergence, i.e., if two countries can be described with similar parameters (e.g. savings rate), the initially poorer country will produce faster growth. However, this can have limited relevance from an economic policy perspective. What is important is the lack of absolute 
convergence. Why is the savings rate (or other parameters) not the same in different countries? How can the observed income disparities be reduced by changing them (Acemoglu 2016)?

The investigation of economic growth has been one of the key research topics in economics. Czárl (2005) underlined that it is one of the oldest fields of study in economics, but when the concept emerged is controversial. He argued that countries treat economic growth as a primary economic and political goal, and he pinpointed that countries with rapid economic growth are moving forward in the ranking of nations and setting an example for emerging ones. He emphasised that if the economy grows, the country's domestic output will expand, and an increase in its per capita value will mean an improvement in the living standards of the population. He also pointed out that economic growth is, therefore, one of the most significant factors in the long-term economic success of nations.

\section{Factors of economic growth: general economic indicators, demographic and labour market processes, foreign direct investment, foreign trade openness}

The most important factors of economic growth are GDP per capita, the activity rate, the employment rate, the unemployment rate, foreign development investment (FDI) and foreign trade openness.

GDP shows the total value of goods produced by a country's population and companies. He pointed out that two types can be distinguished: nominal GDP and real GDP. Nominal GDP shows the monetary value of all goods produced by a country's population and companies, but this excludes the impact of inflation. In contrast, real GDP already takes inflation into account. GDP per capita is a ranking for different countries, referring to the standard of living in each country. A higher GDP per capita means a higher standard of living (The Centre for Analysis 2017).

Let me introduce the following example regarding the definition of purchasing power parity. How much would the forint be worth in dollars, pounds or yen in a world without borders, where markets are not distorted and are free to operate everywhere? In such a world, everything would cost the same everywhere, as would exchange rates. If the same car costs $\$ 15,000$ in New York and $£ 9000$ in London, $\$ 1$ is worth $£ 0.6$. But this is not how the economy works. Exchange rates usually differ from purchasing power parity. One currency is undervalued, and the other is overvalued. So if the $\$ 1$ exchange rate is 0.5 pounds, then the dollar is undervalued, and the pound is overvalued. The Big Mac Index is a measure of currency comparison that differentiate the price of Big Mac sandwiches in dollars around the world. The Big Mac Index can then be compared to exchange rates, and then it becomes clear which currency is undervalued or overvalued (Marron 2010).

The GDP per capita, the employment rate, the share of foreign direct investment will decrease, and the unemployment rate will increase in 2020. Furthermore, young 
and more qualified workers will migrate from underdeveloped regions to developed parts of the country. As a result, age structure and educational standards will deteriorate in these regions (Barna and Molnár 2019).

One of the biggest global social challenges of the $21^{\text {st }}$ century is the continued growth of the world's population, which could reach or even exceed 9 billion by 2050 (Bertalan and Sarudi 2016).

Areas where foreign-controlled companies are established can stimulate the economy. However, there is a lack of innovative developments or a graduate workforce in these areas. Varga and Lengyel (2019) emphasised that it can be considered an advantage if they bring market relations or technology transfer.

A significant factor for growth performance is foreign trade openness, which is the ratio of exports and imports to GDP (Alotaibi and Mishra 2014).

\section{Methodology}

In terms of the data collection method, the research is considered secondary research, as already available data related to the topic was collected.

First, I demonstrate the growth performance of the region over the past 25 years and the characteristics of its various phases, and then I discuss the topic of fiscal policy and its connections to economic growth. The surveyed countries include the eleven Central and Eastern European countries of the European Union: Bulgaria, the Czech Republic, Estonia, Croatia, Poland, Latvia, Lithuania, Hungary, Romania, Slovakia and Slovenia. Although there are substantial differences between the growth paths of individual countries, similarities also emerge. Then I present the demographic and labour market processes of the convergence period, and finally, I will focus on FDI and economic openness.

\section{Research findings}

In this chapter, research findings will be discussed in the light of economic growth, general economic indicators, demographic and labour market processes, FDI and foreign trade openness.

\section{Convergence with Western Europe}

The similarities and differences of the convergence paths can be outlined. At the end of the 1990s, there was no coherent convergence trend, as even more countries in the region suffered from a decline during this period. Poland, Slovenia and the three Baltic states were already able to show clear real convergence with Western European countries between 1995 and 2000. From 2000 onwards, however, until 2007-2008, there was 
a mostly rapid convergence in the whole region. After 2008, convergence was also typical. In the Baltic States, GDP per capita in purchasing power parity reduced between 2007 and 2008 compared to Western European countries. This period was followed by a rapid convergence, as a result of which all three countries have now reached and exceeded their relative position before the recession. A slowdown of convergence can be identified in Bulgaria, Hungary, Romania and the Czech Republic, while segregation can be demonstrated in Croatia and Slovenia (Table 1).

Table 1. GDP per capita as a percentage of the average of Western European EU countries on PPP in the last 25 years (\%)

\begin{tabular}{|l|c|c|c|c|}
\hline \multicolumn{1}{|c|}{ Country/Year } & 1995 & 2000 & 2008 & 2019 \\
\hline Bulgaria & 29.00 & 19.58 & 29.80 & 35.12 \\
\hline Czech Republic & 65.30 & 49.50 & 58.79 & 61.03 \\
\hline Estonia & 30.10 & 28.81 & 48.40 & 55.67 \\
\hline Croatia & - & 33.98 & 44.02 & 43.25 \\
\hline Poland & 36.40 & 32.51 & 38.83 & 48.61 \\
\hline Latvia & 28.40 & 24.75 & 41.29 & 46.25 \\
\hline Lithuania & 29.50 & 25.86 & 44.02 & 54.60 \\
\hline Hungary & 43.20 & 36.20 & 44.02 & 48.82 \\
\hline Romania & 27.30 & 18.10 & 35.55 & 46.25 \\
\hline Slovakia & 40.30 & 34.72 & 50.04 & 49.04 \\
\hline Slovenia & 63.10 & 55.41 & 62.89 & 58.24 \\
\hline
\end{tabular}

Source: Eurostat, Purchasing power... (n.d.).

\section{Labour market processes}

Tables 2-7 show the three most crucial labour market indicators between 1997 and 2019 in Central and Eastern Europe. I excluded 1995 and 1996 since the necessary data of the countries are not available in 1995, and in 1996, only the data of Hungary and Slovenia are available.

Tables 2 and 3 show that the employment rate had an increasing trend in all countries between 1997 and 2019.

Tables 4 and 5 demonstrate that the activity rate increased until 2008, with the exception of Lithuania. It showed a growing trend between 2008 and 2019 in Bulgaria, Estonia, Lithuania, Hungary and Slovakia, while in other countries, a decline was observable. Furthermore, between 1997 and 2019, the activity rate indicated an upward trend in all countries except Romania.

Tables 6 and 7 highlight that the unemployment rate decreased until 2008, with the exception of Romania and the Czech Republic. It marked a declining trend between 2008 and 2019 in all countries. Furthermore, between 1997 and 2019, the unemployment rate indicated a downward trend in all countries. 


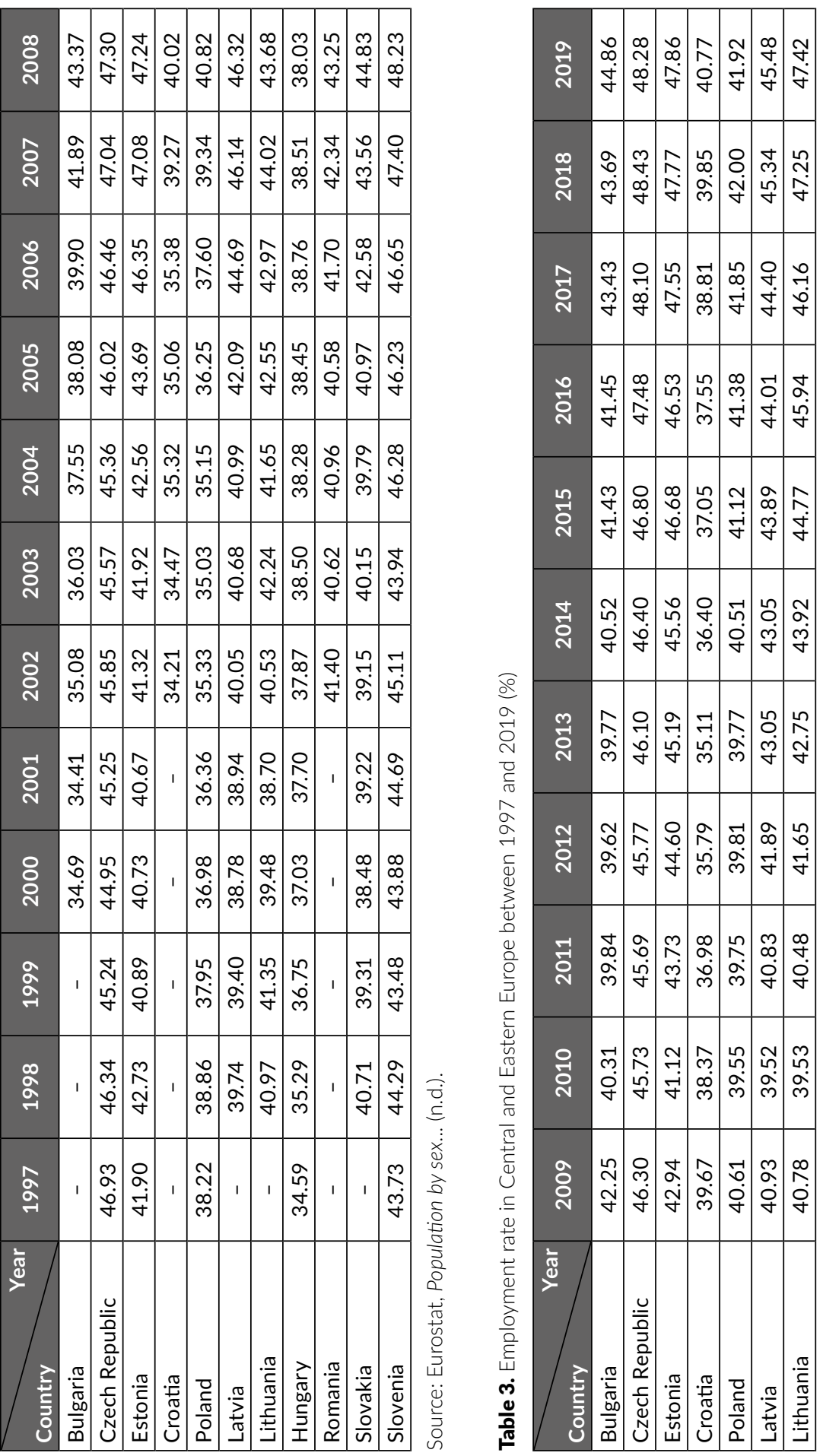


Economic Development and Growth in Central and Eastern Europe

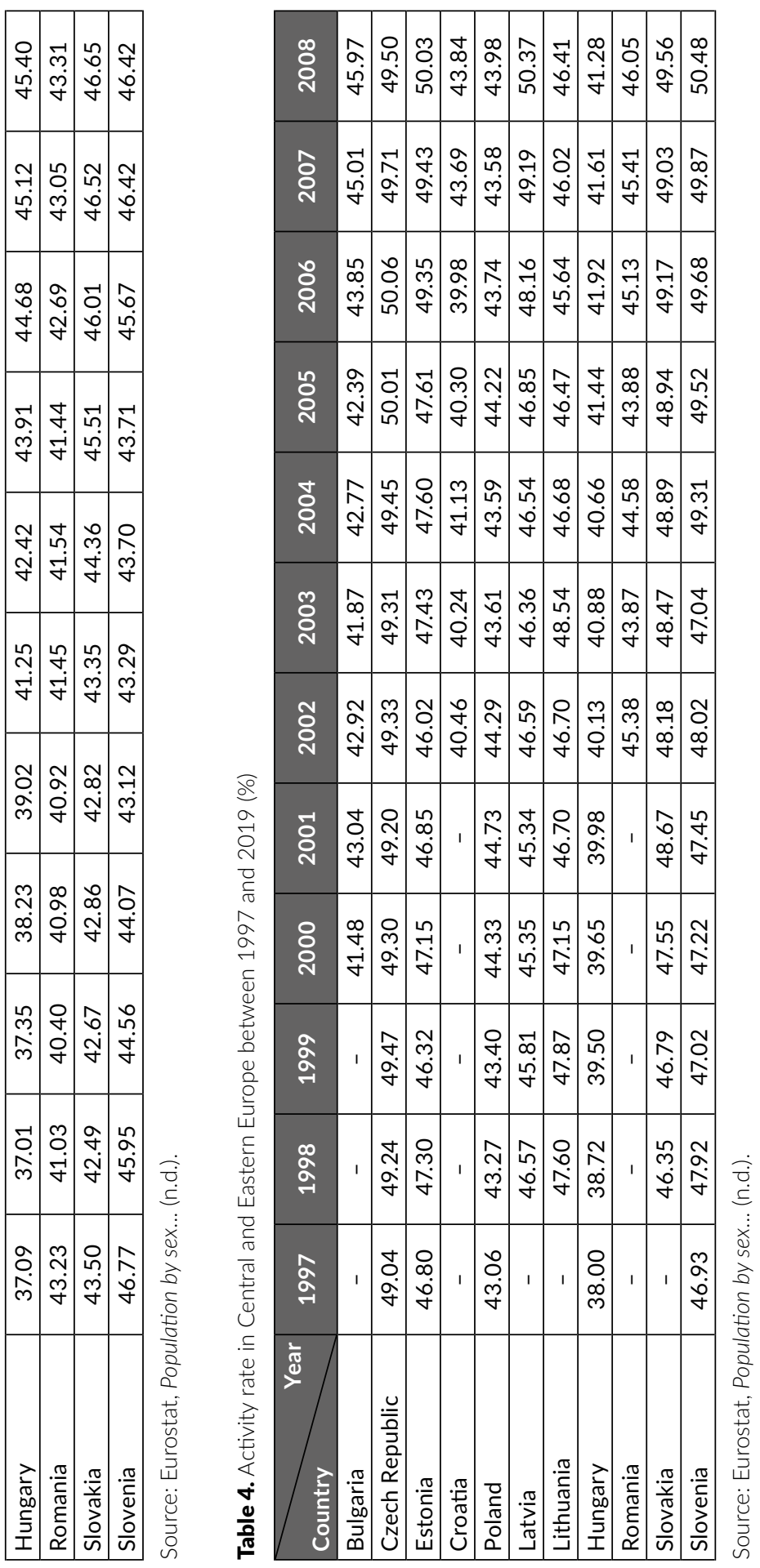




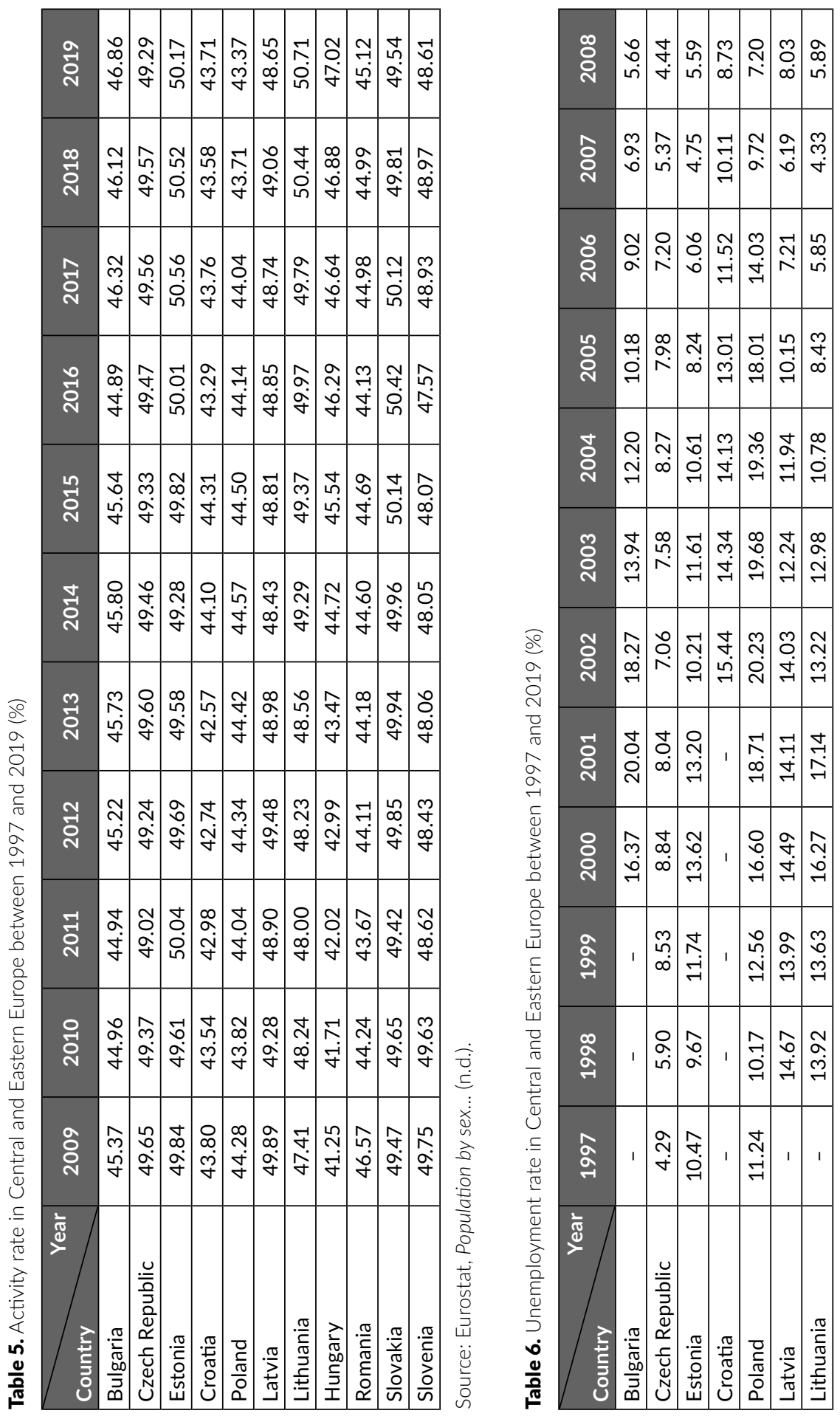


Economic Development and Growth in Central and Eastern Europe

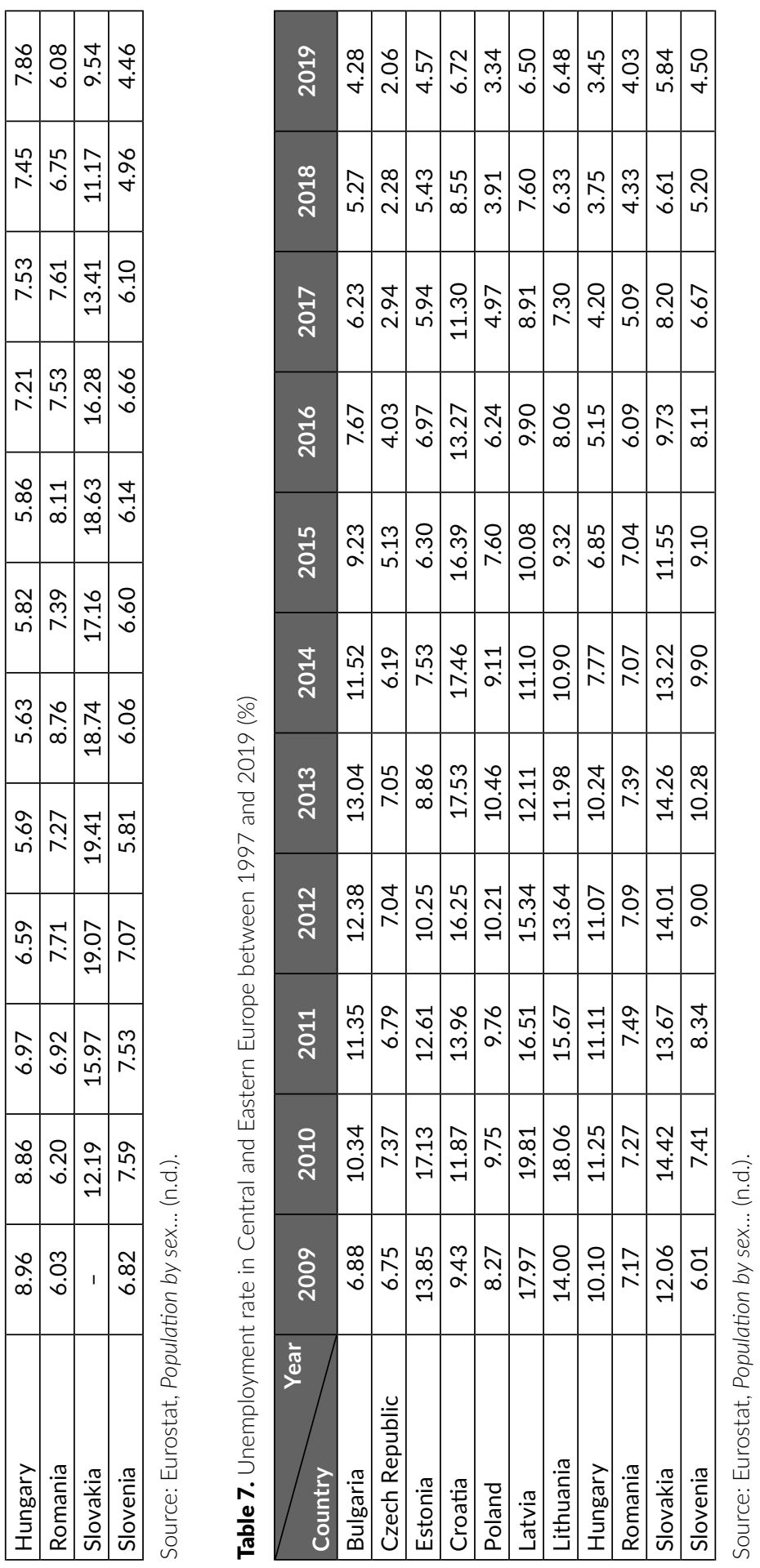




\section{Csilla Polster}

\section{FDI and foreign trade openness}

A developing, open economy cannot expand its capital stock solely from domestic resources. FDI also played a significant role in this process in the countries of the region; however, naturally, differences can also be observed (Figures 1 and 2).

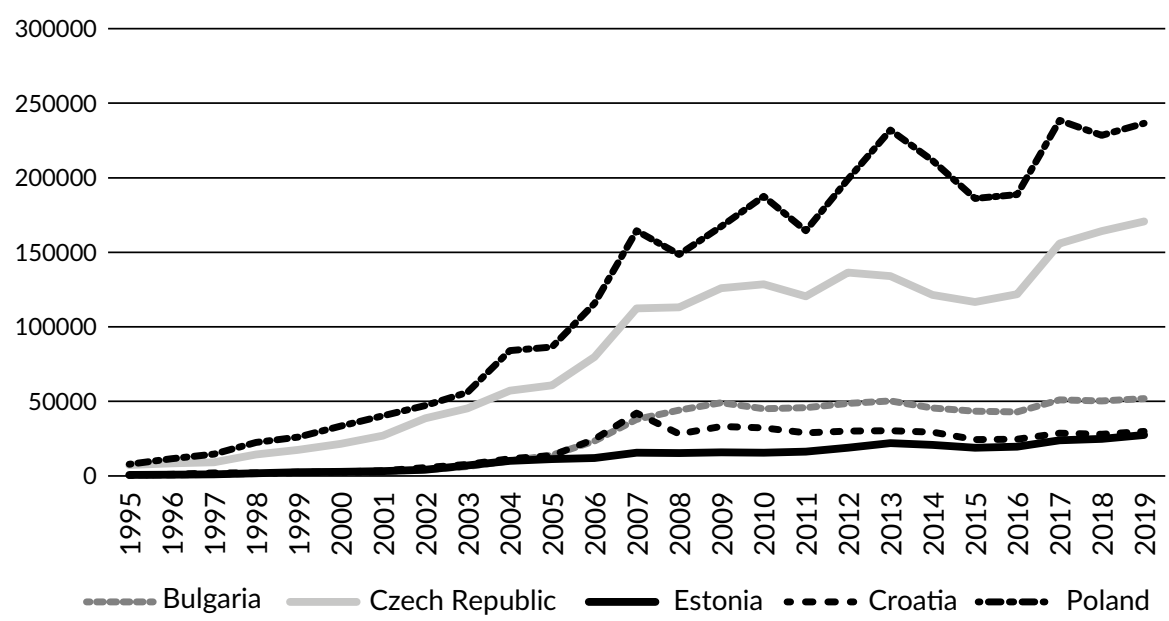

Figure 1. The incoming FDI stock in Central and Eastern Europe as a percentage of GDP in the last 25 years

Source: Eurostat, Population by sex ... (n.d.).

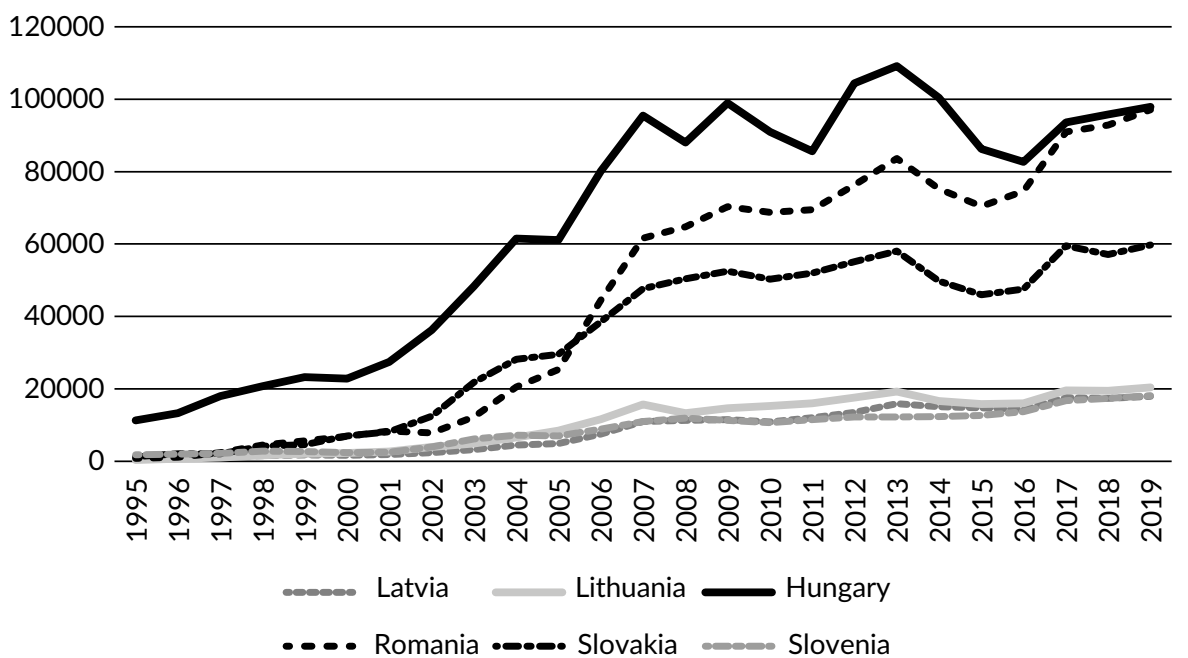

Figure 2. The incoming FDI stock in Central and Eastern Europe as a percentage of GDP in the last 25 years

Source: Eurostat, Population by sex... (n.d.). 


\section{Conclusion}

The study addressed the issues of economic growth. Firstly, the most important growth theories were presented. Secondly, the performance of Central and Eastern European countries was investigated over the past 25 years in the light of the theoretical background.

The growth performance of eleven EU member states was examined in the last 25 years, and similarities and differences were also introduced. The most important statements are the following:

- In terms of economic growth, the last 25 years can be divided into three distinct phases in each country in the region: 1) transformational decline, 2) convergence period, 3) recession.

- The recession was followed by rapid growth everywhere, as a result of which all countries showed convergence with Western European countries. Overall, the whole region underwent a very significant upswing during this period. Of course, this also meant a significant degree of convergence with the more developed countries of Western Europe, as shown by the data in Table 1.

- The driver of rapid growth was capital accumulation.

- Rapid capital accumulation would not have been possible without a large inflow of FDI.

Growth prospects for the countries:

- The inflow of FDI has decelerated significantly since 2008 and will not be able to restart easily in the near future due to the global decline in investment and risk propensity.

- As a result of emigration, serious tensions have arisen in the labour market, and in addition to the existing long-term unemployment, there is also a growing labour shortage.

In my view, in order to achieve substantial economic growth in the coming years and decades and to be able to reduce the gap with Western Europe in accordance with the continuously formulated convergence goals, it is absolutely necessary to improve the quality of the institutional system. This can lead to the stability of economic policy.

\section{References}

Acemoglu, D. (2016), Introduction to Modern Economic progress, Department of Economics, Massachusetts Institute of Technology, Cambridge, https://www.theigc.org /wp-content/uploads/2016/06/acemoglu-2007.pdf (accessed: 9.08.2020).

Alotaibi, A.R., Mishra, A.V. (2014), Emerging Markets and the Global Economy, [in:] M. Arouri, S. Boubaker, D. Nguyen (eds.), Emerging Markets and the Global Econo$m y$, Academic Press, Oxford, Emerging Markets and the Global Economy, Oxford, 
pp. 749-771, https://www.sciencedirect.com/science/article/pii/B97801241154910 00314 (accessed: 9.08.2020).

Barna, K., Molnár, T. (2019), Veszprém megye településeinek társadalmi és gazdasági fejlettsége [Social and Economic Development of Settlements of Veszprém County], "Deturope", 11 (2), pp. 169-184, http://www.deturope.eu/index.php?navi=101\&vo l=42 (accessed: 9.08.2020).

Bathelt, H., Buchholz, M. (2019), Outward Foreign Direct Investments as a Catalyst of Urban-Regional Income Development? Evidence from the United States, "Economic Geography”, 95 (5), pp. 442-466, https://www.tandfonline.com/doi/pdf/10.1080 /00130095.2019.1665465?need Access=true (accessed: 12.08.2020).

Bertalan, P., Sarudi, Cs. (2016), A globalizáció és a kohéziós politika hatása Magyarországon a 2014-2020-as idöszakban [Globalisation and the Effect of the Cohesion Policy in Hungary in 2014-2020], "Deturope", 8 (2), pp. 73-87, http://www.deturo pe.eu/index.php?navi=101\&vol=23 (accessed: 9.08.2020).

Bláha, D., Labem, U., Nováček, A., Budějovice, C. (2016), How Central Europe is Perceived and Delimited, "Mitteilungen der Österreichischen Geographischen Gesellschaft”, 158, pp. 193-214, http://austriaca.at/0xclaa5576\%200x003aad6f.pdf (accessed: 31.08.2020).

Czárl, A. (2005), Szerkezeti átalakulás, gazdasági növekedés meghatározó tényezői és hatásai az agrárágazatban Magyarországon [Determinants and effects of structural change and economic progress in the agricultural sector in Hungary], Szent István Egyetem, Gazdálkodási- és Szervezéstudományok Doktori Iskola, Doktori (PhD.) értekezés, Gödöllő, http://archivum.szie.hu/JaDoX_Portlets/documents/do cument_3156_section_3299.pdf (accessed: 9.08.2020).

Eichenauer, P., Klee, A. (2013), Regionalentwicklung, Migration und Fläche, "Raumforschung und Raumordnung. Spatial Research and Planning", 71 (6), pp. 453-454, https://doi.org/10.1007/s13147-013-0260-9

Eurostat, Population by sex, age, country of birth and labour status (1 000), https://ec .europa.eu/eurostat/web/products-datasets/-/lfsq_pgacws (accessed: 31.08.2020).

Eurostat, Purchasing power adjusted GDP per capita, https://ec.europa.eu/eurostat/web /products-datasets/-/sdg_10_10 (accessed: 31.08.2020).

Gudowski, J., Piasecki, R. (2020), Foreign Direct Investment from Emerging Markets. Theory and Practice, "Comparative Economic Research. Central and Eastern Europe", 23 (2), pp. 7-19, http://doi.org/10.18778/1508-2008.23.09

Kilper, H., Klee, A. (2018), Über soziale Verwundbarkeit, Planungsmethoden und Arbeitskräftemobilität, "Raumforschung und Raumordnung. Spatial Research and Planning”, 76 (6), pp. 483-484, https://doi.org/10.1007/s13147-018-0561-0

Korcelli, P., Korcelli-Olejniczak, E. (2015), Metropolitan Transition in East-Central Europe, "Mitteilungen der Österreichischen Geographischen Gesellschaft", 157, pp. 29-49, http://austriaca.at/0xclaa5576\%200x0032bbaf.pdf (accessed: 31.08.2020).

Krajewska, A., Krajewski, S. (2020), The Labor Market in Poland and the Social Responsibility of the State and Business: Comparative Aspects, "Comparative Economic Research. Central and Eastern Europe”, 23 (1), pp. 93-109, https://doi.org/10.18 778/1508-2008.23.06 
Lengyel, I., Varga, A. (2018), A magyar gazdasági növekedés térbeli korlátai, helyzetkép és alapvetö dilemmák [Spatial constraints, situation and basic dilemmas of Hungarian economic growth], "Közgazdasági Szemle”, LXV, pp. 499-524, http://real.mtak .hu/79542/1/03_Lengyel_VargaA_u.pdf (accessed: 9.08.2020).

Manić, E., Popović, S., Mitrović, D. (2016), Is there a "Chinese Wall” in Europe? A Glance at the Development of Socio-economic Disparities in Europe, Räumliche Disparitäten Spatial Disparities, "Mitteilungen der Österreichischen Geographischen Gesellschaft", 158, pp. 133-148, http://austriaca.at/0xclaa5576\%200x003aad 69.pdf (accessed: 31.08.2020).

Mankiw, N.G., Romer, D., Weil, D.N. (1992), A contribution to the empirics of economic growth, "The Quarterly Journal of Economics", May, pp. 407-437, https://eml.berke ley.edu/ dromer/papers/MRW_QJE1992.pdf (accessed: 9.08.2020).

Marron, D. (2010), 30-Second Economics, Icon Books, London.

Molnár, E., Lengyel, I.M. (2016), Integration into global production networks and path-dependence: the footwear industry in post-socialist Hungary, "Zeitschrift für Wirtschaftsgeographie”, 60 (4), pp. 171-185, https://doi.org/10.1515/zfw-2016-0024

Parnreiter, Ch. (2013), 20 Jahre NAFTA. Mexikos gescheitertes upgrading in globalen Güterketten, “Zeitschrift für Wirtschaftsgeographie”, 57 (4), pp. 216-236, https:// www.researchgate.net/publication/272505438 (accessed: 9.08.2020).

Somogyi, F. (2016), Meta-és makroökonómia [Meta- and macroeconomics], Universitas-Győr Nonprofit Kft., Győr.

The Centre for Analysis (2017), GDP: nominális, reál GDP jelentése, GDP adatok értelmezése gazdasági döntéseink során [GDP: nominal, real GDP report, interpretation of GDP data in our economic decision], https://elemzeskozpont.hu/gdp-nomi nalis-real-gdp-jelentese-gdp-adatok-ertelmezese-gazdasagi (accessed: 9.08.2020).

Varga, A., Lengyel, I. (2019), Földrajz és gazdasági növekedés magyarországon - továbblépés és újabb diagnózisok [Geography and economic progress in hungary - progress and new diagnoses], "Közgazdasági Szemle", 66 (6), pp. 597-606, https://doi.org/10 .18414/KSZ.2019.6.597

Witkowska, J. (2020), The European Union's Screening Framework for Foreign Direct Investment: Consequences for External Relations, "Comparative Economic Research. Central and Eastern Europe”, 23 (1), pp. 19-36, https://doi.org/10.18778/1508-2008 .23 .02

Wysokińska, Z. (2018), Implementing the Main Circular Economy Principles within the Concept of Sustainable Development in the Global and European economy, with Particular Emphasis on Central and Eastern Europe - the Case of Poland and the Region of Lodz, "Comparative Economic Research. Central and Eastern Europe", 21 (3), pp. 75-93, https://doi.org/10.2478/cer-2018-0020 


\section{Rozwój i wzrost gospodarczy w Europie Środkowo-Wschodniej}

Opracowanie przedstawia wyniki badania wzrostu gospodarczego w Europie Środkowo-Wschodniej w ciągu ostatnich 25 lat. Gospodarka może być uważana za istotny temat analiz w każdym kraju, ale jest szczególnie interesująca w przypadku krajów rozwijających się. Jednym z podstawowych dążeń Unii Europejskiej jest konwergencja państw członkowskich, czyli zmniejszanie dysproporcji rozwojowych, co można osiągnąć poprzez szybszy wzrost gospodarczy krajów słabiej rozwiniętych.

Teoria wzrostu jest jednym z głównych tematów w ekonomii. Jej ogromne znaczenie wynika z tego, że chęć rozwoju jest jedną z głównych sił napędowych ludzkości.

Celem badania jest wskazanie istotnych różnic między ścieżkami rozwoju jedenastu krajów członkowskich Unii Europejskiej z Europy Środkowo-Wschodniej oraz cech wspólnych.

Po uprzednim przedstawieniu teorii wzrostu, pokazano osiągnięcia w obszarze wzrostu badanych państw członkowskich z Europy Środkowo-Wschodniej.

W badaniu wzięto pod uwagę PKB per capita, liczbę ludności, migracje, wskaźnik aktywności zawodowej, wskaźnik zatrudnienia, stopę bezrobocia, bezpośrednie inwestycje zagraniczne oraz otwartość handlu zagranicznego.

Słowa kluczowe: wskaźniki ekonomiczne, procesy na rynku pracy, wzrost gospodarczy

\begin{tabular}{|l|l|}
\hline \multirow{2}{*}{ C. C) by the author, licensee Łódź University - Łódź University Press, } \\
tódź, Poland. This article is an open access article distributed under \\
the terms and conditions of the Creative Commons Attribution \\
license CC-BY-NC-ND 4.0 \\
(https://creativecommons.org/licenses/by-nc-nd/4.0/) \\
\cline { 2 - 2 } & Received: 2021-05-25. Verified: 2021-07-14. Accepted: 2021-08-11. \\
\hline
\end{tabular}

